\title{
Using African Indigenous Languages in Science Engagement to Increase Science Trust
}

\author{
Grace Kago ${ }^{1,2 *}$ and Mohamed Cissé ${ }^{2 *}$ \\ ${ }^{1}$ Department of Molecular Biosciences, LaMontagne Center for Infectious Disease, The University of Texas at Austin, Austin, TX, \\ United States, ${ }^{2}$ African Diaspora Science Federation (ADSF), Indianapolis, IN, United States
}

Keywords: science engagement, African Indigenous Languages, science communication, multilingualism, Strategic Communication

\section{INTRODUCTION}

In 2018, The Wellcome Global Monitor reported that only an average of 15.6\% (average calculated from chart 3:1) of the African population have high trust in scientific institutions and scientists (WGM report, 2018). This report (p. 58) cited two primary factors associated with the level of trust of

OPEN ACCESS

Edited by:

Marina Joubert,

Stellenbosch University, South Africa

Reviewed by:

Ana Maria Porras,

Cornell University, United States

Nina Hunter

University of KwaZulu-Natal, South

Africa

*Correspondence:

Grace Kago

contact@adsf.club

Mohamed Cissé

mohamed.cisse@adsf.club

Specialty section:

This article was submitted to

Science and Environmental

Communication,

a section of the journal

Frontiers in Communication

Received: 15 August 2021 Accepted: 30 November 2021

Published: 05 January 2022

Citation:

Kago G and Cissé M (2022) Using African Indigenous Languages in Science Engagement to Increase

Science Trust.

Front. Commun. 6:759069.

doi: 10.3389/fcomm.2021.759069 a person in scientists: 1) learning and understanding science at school or college and 2) confidence in key societal institutions (the government, military, and judiciary). In a study interrogating how courtroom linguistic choices impact confidence in the institution of the justice system, Liu and Baird discovered that confidence levels are lowest when only a majority language is used in the courtroom, and that use of either a minority language and/or a lingua franca increases confidence levels in the judicial institution (Liu and Baird, 2012). Examination of both teacher (Alidou et al., 2006; Njoroge, 2011; Kibirige and Mogofe, 2021; Semeon and Mutekwe, 2021) and student performances (Prophet and Dow, 1994; Rollnick and Rutherford, 1996; Manzini, 2000; Mwinsheikhe, 2002; Brock Utne, 2004; Mammino, 2010; Mahlasela, 2012; Charamba 2019) using more familiar languages as opposed to Western languages has consistently shown increased understanding of scientific concepts. Students taught in languages familiar to them also produced better results in exams and there were fewer repeaters (Wilmot, 2003; Bender et al., 2005; Alidou et al., 2006; Kioko et al., 2014).

Policies that address the importance of using "understandable" or "familiar languages" to discuss science topics have been proposed in documents like the Lagos Declaration and Call to Action on Science Communication and the Public Learning and Understanding of Science (PLUS), which was produced during the 2nd African Conference on Emerging Infectious Diseases and Biosecurity in 2016 (African Gong, 2016). This concept is also addressed within "Priority 3" and expanded in chapter six of the 10-year Science, Technology, and Innovation Strategy for African Union (2014) (STISA-2024), which was drafted during the 23rd Ordinary Session of African Union Heads of State and Government Summit in June 2014 (African Union, 2014). Thus, we believe that if we continue to encourage a commitment to promote science and its implications in daily life, culture, and environment (science engagement) in more African indigenous languages (AILs), then understanding, confidence, and ultimately trust in science across large audiences on the African continent will increase.

\subsection{Status of science engagement on the African Continent}

Historically, while there have been science engagement efforts in Africa, they have not been without barriers (Joubert, 2001; The African Technology Policy Studies Network, 2010). An assessment (Ndlovu et al., 2016) of the science engagement of African researchers from a prominent university in Zimbabwe cited barriers such as 1) precarious research funding which can lead to low priority of science engagement, 2) low institutional rewards, 3) government censorship of certain research 
topics in the public domain, 4) perceived low public science literacy, 5) lack of training programs to equip academics with science communication skills, and 6) high teaching loads and lack of time that prohibit extracurricular activities. Other barriers include the challenge of making science engagement materials in the many languages on the continent (The African Technology Policy Studies Network, 2010; Karikari et al., 2016). Additionally, many past science engagement programs in Africa have used models that are tailored to Western donor mandates and little to no relevance to the local context (The African Technology Policy Studies Network, 2010, p 23-24), or are largely one-time events with no long-term evaluation, coordination, infrastructure, or sustainability plans (Joubert, 2001).

In recent years, there has been an increase in impactful science engagement initiatives both at the nonprofit and institutional level. At the nonprofit level, some of the organizations doing meaningful science engagement all around Africa include: Eh! Woza, ProjeKt inspire, Yiya Solutions, Ikala STEM, Practical Education Network (PEN), Global Lab Network, Super Scientist, Travelling Telescope, Mavis Talking Books, MOBILELABO, PlayAfrica, Under the Microscope (UTM), New Education for Radical Development (iNERDE), Fun and Education Global Network (FEGNe), and The STEM Impact Center Kenya, to name a few (Stephanie Okeyo, personal communication, September 28, 2021). There has also been an increase in science, technology, engineering, arts, and mathematics (STEAM)-based mainstream media television shows for children like Ubongo Kids and Super Sema. To equip and train science engagers, there are institutional programs like the Training Center in Communication at the University of Nairobi (Okeyo, 2021), the Centre for Research on Evaluation, Science, and Technology (CREST) at Stellenbosch University, and workshops from the Pan-African Network for the Popularization of Science and Technology and Science Communication in Africa (African Gong).

\subsection{Strides to increase the feasibility of science engagement in African indigenous languages}

1.2 1 Strategies to overcome the barrier of language multiplicity on the continent

The first glaring topic to address regarding feasibility of science engagement in AILs is the fact that there are over 2,000 African languages (Obanya, 1999; Skutnabb-Kangas et al., 2003). Which languages should be used and why? Linguists have categorized African languages based on: 1) languages that are common across multiple countries, yielding $\sim 20$ or so languages called "interAfrican” languages (Appendix C; UNESCO, 1981; Roy-Cambbell, 2006), 2) the highest number of language-speakers, which generates a list of $\sim 10-15$ languages which are spoken by over 15 million speakers each (Appendix B; Roy-Campbell, 2006), and 3) language harmonization, where languages are grouped in linguistic families, and common orthographies are developed (Prah, 2003 p 27; Appendix B; Roy-Cambbell, 2006). Thus, while indeed there are many languages spoken in Africa, there are ways to pick regionally relevant languages to use for science engagement.

\subsubsection{Resources that will increase throughput of translation for science engagement in African indigenous languages}

The next concern to address is the issue of translation. To develop fast, accurate, and accessible translation of technical content in different AILs, we think that this process must be automated. The organization (Ghana, 2020) NLP (Natural Language Processing) is one of many organizations developing matched lists of words and sentences that allow a computer to connect and correlate meanings in two or more languages. In January 2021, this organization developed a parallel bilingual machine translation training corpus for English and Akuapem Twi, spanning 25,421 sentence pairs in total (Azunre et al., 2021a; Azunre et al., 2021b). The social enterprise Zindi regularly hosts competitions to generate data sets that can be used to train computers to translate African languages. So far, they have received training data set contributions from African data scientists that cover the Wolof (Senegal), Hausa, Igbo, Yoruba (Nigeria), Fongbe, Ewe, Kabiye (Benin and Togo), Tunisian Arabic (Tunisia), Kiswahili (Kenya and Tanzania), and Chichewa (Malawi) languages (Zindi, 2020, $1^{\text {st }}$ Round of A14D-African Language Data-Set challenges, 2020).

Additionally, the pan-African Open Access platform AfricArxiv recently announced a "Decolonize Science" project in collaboration with the NLP research organization Masakhane. In this project, they aim to translate original research papers into six diverse African languages that include isiZulu, Northern Sotho, Yoruba, Hausa, Luganda, and Amharic (Obanda, 2021; Wild, 2021). Translating technical subject matter in different languages is also under way at the FAO (Food and Agriculture Organization) of the United Nations (AGROVOC, 2021).

\subsection{Do African indigenous languages contain the range for technical Discourse?}

Digital translation capacity is all well and good, but someone might ask: "Can AILs convey scientific concepts?" Broadly, there are several ways that scientists introduce words to scientific lexicon: 1) words with two meanings (For example, the word "ring" can have two meanings depending on context: mathematics or jewelry. People with an academic background in mathematics have that in mind. For nonmathematicians, this is a prime opportunity for a science engager to start building concept bridges), 2) words that remain unchanged from another language, or 3) new words altogether (Gillet, 2021; Flood, 1960; Ademowo, 2012). Furthermore, dialogue across languages is not unusual, because while current science culture is heavily monoglot, multilingualism was historically a big component of scientific knowledge production (Gordin, 2015).

There are examples of scholars who have developed technical words in AILs. For example, Dr. Thembla Dlodlo has laid out a comprehensive template for how to devise new words to describe Physics concepts in the Nguni language (Dlodlo, 1999), and Dr. Christopher Chetsanga published, a Science-English dictionary 
in the Shona language (Chetsanga, 2014). The Kenyan scholar-author Nanjala Nyabola, along with a team of linguists has created translation cards to communicate digital rights and data literacy vocabulary in various dialects of the Kiswahili language. Nyabola and efforts of her team are timely and relevant especially considering the recent efforts of Kenya to digitize population biometric data (Betteridge-Moes, 2021; Nyabola, 2021).

\subsection{Just like other languages, African indigenous languages can develop and adapt adequate Terminology}

Borrowing from concepts in evolutionary biology, which describe how an organism can evolve and adapt to its environment (Morgan, 1903; Newberry et al., 2017), so can languages evolve, drift (Ventura et al., 2021), and adapt to the new content that they will need to describe (Greenhill et al., 2017; Tirosh, 2021). Languages like Sheng (Kang' ethe-Iraki, 2004; Kim, 2015) from Kenya and various Pidgin and Creole languages morph and adapt to changing times all the time (Roberge, 2011; Tirosh, 2021). Formal language-modernization approaches are not new, and we point our readers to the work of Eliezer Ben Yehuda, who was instrumental in modernizing the Hebrew language (Haddad, 1998). Another example of language modernization is the work of Fukuwa Yukichi (Havens, 1971), who was responsible for translating many subjects ranging from chemistry and the arts from English to Japanese language. Both the works of Yehuda and Yukichi were seminal in modernizing the Hebrew and Japanese languages, respectively, and their success makes one believe that a similar outcome is possible for African languages.

\section{DISCUSSION}

\subsection{Where the responsibility to start engagement initiatives in African indigenous languages lies}

We believe that integrating more science engagement in AILs will need to be supported by both institutions and individuals. Governments and institutions can provide the resources and incentives for scientists and linguists to create words which can be integrated into NLP translation algorithms, which can then equip individual science engagers and journalists with the words to create educational content in AILs. We strongly encourage the inclusion of native language speakers in the creation and selection of words. A recent paper (Clark et al., 2021) detailing the development of an organic chemistry American Sign Language (ASL) lexicon for the deaf and hard of hearing scholars provides a good model for how to build an inclusive team to develop new words. An example of native language speakers to include on such teams could be vernacular language musicians because they often possess both the linguistic aptitude to find innovative ways to communicate, and they already have established audiences.

\subsection{Is there a precedent for science engagement in a non-African vernacular language?}

At this juncture, a question that might arise is: are there any documented successful vernacular language science engagement efforts? The audio-science digest Janasuddi, produced in the Indian language of Kannada is a prime candidate. The word jana means both smart and knowledge, and suddi means news in Kannada (Barath, 2019). This initiative is run by Kollegala Sharma, a scientist from Karnataka, India (Sharma, 2019). He has been producing this weekly $\sim 20$-min science podcast since September 2017 (Barath, 2019). His program reaches over 2,000 people via WhatsApp, and over 100,000 people via local radio shows which broadcast his show (K. Sharma, 2021). As of the writing of this essay, according to theTwitter page of Mr. Sharma, he has produced 880 episodes of Janasuddi in the last 4 years. Furthermore, while Mr. Sharma scripts the show, he does involve his audience both locally and in the diaspora, to provide voiceovers, and counts the principal scientific advisor for the Indian Government as a fan (Barath, 2019). The work of Mr. Sharma is a powerful case study to show that the use of vernacular languages can be used to engage audiences in science topics.

\section{CONCLUSION}

At this moment in time, scholars are using Data Science, Artificial Intelligence, and Machine-Learning to solve age-old complex problems like protein folding (Jumper et al., 2021), building models to predict the safety of self-driving vehicles in the human context (Pekannen et al., 2021), and reconstructing paintings from the 1900s (Gaskin, 2021). These same fields are generating NLP translation tools to translate beautifully diverse and complex African languages. So, using AILs to facilitate conversations about technical topics is possible.

At an individual level, what can African scientists do? We can reflect on whether we ourselves can explain aspects of our scientific expertise in African languages. Some examples include the linguist Bienvenu Sene Mongaba, who has created an interpretation of the Periodic Table in the Lingala Language (Sene Mongaba, 2009), a Youtube channel run by one of the authors of this paper (Kago, 2021), where she creates short videos about cell biology topics in the Gikuyu language of Central Kenya, and a book on South African frogs in isiZulu and English (Phaka and Ovid, 2021).

One of the outcomes of the current COVID-19 pandemic is an increased urgency to establish robust biotechnology infrastructures on the African continent. Both the African Union and Africa-CDC have articulated goals to increase the production of vaccines on the continent from 1\% to $60 \%$ by 2040 (Irwin, 2021). To achieve these goals, African countries need not only logistic and technical capacity, but also societal trust in scientific interventions. We posit that using AILs in scientific engagement will go a long way to increase sustainability and longevity of efforts such as these.

"African governments must look at the languages spoken by their citizens in terms of how they can be utilized to contribute to the welfare of the citizens. It is in preparing our languages for 
enhanced gainful utilization that we develop them; paradoxically so they may develop us."-Okoth-Okombo (2001).

\section{AUTHOR CONTRIBUTIONS}

MC: Conceptualization and original draft. GK: Current Manuscript. Both authors edited and contributed to the final manuscript revision and read and approved the submitted version.

\section{REFERENCES}

Ademowo, A. J. (2012). Indigenous Languages and Techno-Scientific Development in Africa. Afro-Asian J. Soc. Sci. 3 (33), 28-36.

African Gong (2016). Lagos Declaration and Call to Action on Science Communication and the Public Learning and Understanding of Science (PLUS) in Africa. African Gong. Available at: http://www.africangong.org/ 2016/07/29/lagos-declaration-and-call-to-action-on-science-communicationand-the-public-learning-and-understanding-of-science-plus-in-africa-27-29july-2016-lagos-nigeria/(Retrieved October 8, 2021).

African Union (2014). Science, Technology and Innovation Strategy for Africa 2024. Addis Ababa, Ethiopia: African Union Commission, 46. Available at: https://au. int/sites/default/files/newsevents/workingdocuments/33178-wd-stisaenglish_-_final.pdf (Retrieved October 7, 2021).

AGROVOC (2021). Food and Agriculture Organization of the United Nations. Available at: http://www.fao.org/agrovoc/(Accessed August 2, 2021).

Alidou, H., Boly, A., Brock-Utne, B., Diallo, Y. S., Heugh, K., and Wolff, H. E. (2006). Optimizing Learning and Education in Africa-The Language Factor: A Stock-Taking Research on Mother Tongue and Bilingual Education in Subsaharan Africa. Available at: https://biennale.adeanet.org/2006/doc/document/ B3_1_MTBLE_en.pdf.15-18.

Azunre, P., Osei, S., Addo, S., Adu-Gyamfi, L. A., Moore, S., Adabankah, B., et al. (2021a). NLP for Ghanaian Languages. ArXiv [Preprint] https://arxiv.org/abs/ 2103.15475.

Azunre, Paul., Adu-Gyamfi, L., Lawrence, Appiah., Esther, Akwerh., Felix, Osei., Salomey, Amoaba., et al. (2021b). English-akuapem Twi Parallel Corpus. Zenodo. Data set(0 1, 1). doi:10.5281/zenodo.4432117

Barath, H. (2019). Indian Initiatives Aim to Break Science's Language Barrier. Nature 571 (7764), 289-290. doi:10.1038/d41586-019-01815-1

Bender, Penelope., Dutcher, Nadine., Klaus, David., Shore, Jane., and Tesar, Charlie. (2005). Their Own Language : Education for All. Education Notes. Washington, DC: World Bank. Available at: https://openknowledge.worldbank. org/handle/10986/10331 License: CC BY 3.0 IGO.

Betteridge-Moes, M. (2021). How Kiswahili Tech Terms Are Pushing for Digital Rights in East Africa. Quartz Africa https://qz.com/africa/2036362/kiswahilitech-terms-are-pushing-for-digital-rights-in-africa/.

Brock-Utne, B. (2004). "But English Is the Language of Science and Technology: The Language of Instruction in Africa, with a Special Look at Tanzania,”. UT, 914 March in Paper presented at the CIES conference, January 10th 2021 (Salt Lake City. Available at: http://www.netreed.uio.no/articles/Papers_final/brock_ utne.pdf (Accessed.

Charamba, E. (2019). Learning and Language: towards a Reconceptualization of Their Mutual Interdependences in a Multilingual Science Class. J. Multilingual Multicultural Dev. 42 (6), 503-521. doi:10.1080/01434632.2019.1707837

Chetsanga, C. J. (2014). English-Shona Science and Technology Dictionary: Harare. Harare: College Press Publishers (Pvt) Ltd.

Clark, K., Sheikh, A., Swartzenberg, J., Gleason, A., Cummings, C., Dominguez, J., et al. (2021). Sign Language Incorporation in Chemistry Education (SLICE): Building a Lexicon to Support the Understanding of Organic Chemistry. J. Chem. Educ. doi:10.1021/acs.jchemed.0c01368

Dlodlo, T. S. (1999). Science Nomenclature in Africa: Physics in Nguni. J. Res. Sci. Teach. 36 (3), 321-331. doi:10.1002/(sici)1098-2736(199903)36:3<321:aid-tea6>3.0.co;2-8

\section{FUNDING}

This manuscript is being submitted as an opinion essay under the African Diaspora Scientists Federation (ADSF), a volunteer organization whose aim is two-fold: 1) to bolster STEM capacity building on the African continent by providing mentorship and guidance to diaspora trainees and early career researchers, and 2) to inform policy decisions that both empower African scientists and increase civic science literacy on the continent.

Flood, W. E. (1960). Scientific Words: Their Structure and Meaning. New York: Duell, Sloan and Pearce.

Gaskin, S. (2021). Google Reconstructs Lost Gustav Klimt Paintings with Machine Learning. Ocula the Best in Contemporary Art Icon. Available at: https://ocula.com/magazine/art-news/google-reconstructs-lost-klimt-paintingswith-ai/(Retrieved October 7, 2021).

Ghana, N. L. P. (2020). Ghana Natural Language Processing (NLP). Available at: https://ghananlp.org/(Accessed August 2nd, 2021).

Gillett, A. (2021). Scientific Words: Their Structure and Meaning. from "Using English for Academic Purposes For Students in Higher Education, (UEfAP)" Accessed at: http://www.uefap.com/reading/exercise/texts/sw.htm (Retrieved October 7, 2021).

Gordin, M. D. (2015). Scientific Babel. University of Chicago Press.

Greenhill, S. J., Wu, C.-H., Hua, X., Dunn, M., Levinson, S. C., and Gray, R. D. (2017). Evolutionary Dynamics of Language Systems. Proc. Natl. Acad. Sci. USA 11442, E8822-E8829. doi:10.1073/pnas.1700388114

Haddad, G. (1998). La Renaissance de l'hébreu. Le rêve traversé par Éliézer BenYéhouda. Mémoires du premier enfant hébreu par Ithamar Ben-Avi. La psychose inversée par Gérard Haddad. Bruges: Éditions Desclée de Brouwer.

Havens, T. R. (1971). Fukuzawa Yukichi's an Encouragement of Learning.

Irwin, A. (2021). How COVID Spurred Africa to Plot a Vaccines Revolution. Nature. doi:10.1038/d41586-021-01048-1

Joubert, M. (2001). Report: Priorities and Challenges for Science Communication in South Africa. Sci. Commun. 22 (3), 316-333. doi:10.1177/ 1075547001022003008

Jumper, J., Evans, R., Pritzel, A., Green, T., Figurnov, M., Ronneberger, O., et al. (2021). Highly Accurate Protein Structure Prediction with AlphaFold. Nature 596 (7873), 583-589. doi:10.1038/s41586-021-03819-2

Kago, G. K. (2021). Cell Biology Na Gikuyu. Availabel at: https://www.youtube. com/channel/UC8OqmTZ-kemmMtu7LBYdpXQ (Accessed August 2, 2021).

Kang'ethe-Iraki, F. (2004). Cognitive Efficiency: the Sheng Phenomenon in Kenya. Pragmatics 14 (1), 55-68. doi:10.1075/prag.14.1.02kan

Karikari, T. K., Yawson, N. A., and Quansah, E. (2016). Developing Science Communication in Africa: Undergraduate and Graduate Students Should Be Trained and Actively Involved in Outreach Activity Development and Implementation. J. Undergrad Neurosci. Educ. 14 (2), E5-E8.

Kibirige, I., and Mogofe, A. R. (2021). Integrating Language Literacy in Physical Sciences in Riba Cross District, South Africa. Cjes 16 (2), 547-562. doi:10.18844/cjes.v16i2.5635

Kim, K. (2015). March 2). The Evolution of Sheng As an OPENSOURCE Language. The Evolution of Sheng as an Opensource Language. Availabel at: https://medium.com/@6Dtheory/the-evolution-of-sheng-as-an-opensource-of-language-777ace141e36 (Retrieved September 21, 2021).

Kioko, A. N., Ndung'u, R. W., Njoroge, M. C., and Mutiga, J. (2014). Mother Tongue and Education in Africa: Publicising the Reality. Multiling.Ed. 4, 18. doi:10.1186/s13616-014-0018-x

Liu, A. H., and Baird, V. A. (2012). Linguistic Recognition as a Source of Confidence in the justice System. Comp. Polit. Stud. 45 (10), 1203-1229. doi:10.1177/0010414011434294

Mahlasela, J. T. (2012). Improving Comprehension in Physical Science through Mother-Tongue Subtitling in Secondary Education. Doctoral dissertation. Vanderbijlpark, South Africa: North-West University.

Mammino, L. (2010). "The Mother Tongue as a Fundamental Key to the Mastering of Chemistry Language," in Chemistry as a Second Language: Chemical 
Education in a Globalized Society (American Chemical Society), 7-42. doi:10.1021/bk-2010-1049.ch002

Manzini, S. T. (2000). The Influences of a Culturally Relevant Physical Science Curriculum on the Learning Experiences of African Children (Master's Thesis). Durban, South Africa: University of Durban-Westville.

Sene Mongaba, B. (2009). Tableau périodique des éléménts chimiques/Etanda ebandelaka ya bibuki ya kemi Français-Lingála. Mabiki: Kinshasa-Wavre. Availabel at: http://www.mabiki.net/books/110?locale=fr.

Morgan, T. H. (1903). Evolution and Adaptation. Macmillan.

Mwinsheikhe, H. M. (2001). Science and the Language Barrier: Using Kiswahili as a Medium of Instruction in Tanzania Secondary Schools as a Strategy of Improving Student Participation and Performance in Science. Master Thesis. University of Oslo: Institute for Educational Research.

Ndlovu, H., Joubert, M., and Boshoff, N. (2016). Public Science Communication in Africa: Views and Practices of Academics at the. National University of Science and Technology in Zimbabwe. doi:10.22323/2.15060205

Newberry, M. G., Ahern, C. A., Clark, R., and Plotkin, J. B. (2017). Detecting Evolutionary Forces in Language Change. Nature 551 (7679), 223-226. doi:10.1038/nature24455

Njoroge, M. C. (2011). Linguistic Variation in Multilingual Setting: Evidence from Kenya, Africa. Muller (VDM): Verlag Dr.

Nyabola, N. (2021). Digital Rights Projects " Nanjala Nyabola. Nanjala Nyabola. Availabel at: http://www.nanjalawrites.com/digital-rights-projects/(Accessed August 2, 2021).

Obanda, J. (2021). African Languages to Get More Bespoke Scientific Terms. Availabel at: https://info.africarxiv.org/african-languages-to-get-morebespoke-scientific-terms/(Retrieved October 7, 2021).

Obanya, Pai. (1999). The Dilemma of Education in Africa. Dakar: UNESCO Regional Office.

Okeyo, V. (2021). Public Engagement": New Role for Researchers in Kenya? DDRN. Availabel at: https://ddrn.dk/public-engagement-new-role-forresearchers-in-kenya/(Retrieved October 7, 2021).

Okoth-Okombo, D. (2001). Language Policy: The Forgotten Parameter in African Development and Governance strategiesInaugural Lecture. Nairobi: University of Nairobi Press. Accessed from: http://erepository.uonbi.ac.ke/handle/11295/44378.

Pekkanen, J., Giles, O. T., Lee, Y. M., Madigan, R., Daimon, T., Merat, N., et al. (2021). Variable-Drift Diffusion Models of Pedestrian Road-Crossing Decisions. Comput. Brain Behav. doi:10.1007/s42113-021-00116-z

Phaka, F. M., and Ovid, D. (2021). Life Sciences reading Material in Vernacular: Lessons from Developing a Bilingual (IsiZulu and English) Book on South African Frogs. Curr. Issues Lang. Plann., 1-16. doi:10.1080/ 14664208.2021.1936397

Prah, Kwesi. (2003). "Going Native: Language of Instruction in Education, Development and African Emancipation," in Language of Instruction in Tanzania and South Africa (LOITSA). Editors Birgit. Brock-Utne, Zubeda. Desai, and Martha. Qorro (Dar es Salaam: E \& D Limited), 14-34.

Prophet, B., and Dow, P. (1994). Mother Tongue Language and Concept Development in Science: A Botswana Case Study. Lang. Cult. curriculum 7 (3), 205-216. doi:10.1080/07908319409525178

Roberge, P. T. (2011). "Pidgins, Creoles, and the Creation of Language," in The Oxford Handbook of Language Evolution. doi:10.1093/oxfordhb/ 9780199541119.013.0056

Rollnick, M., and Rutherford, M. (1996). The Use of Mother Tongue and English in the Learning and Expression of Science Concepts: a Classroom-based Study. Int. J. Sci. Edu. 18 (1), 91-103. doi:10.1080/0950069960180108

Roy-Campbell, Z. M. (2006). "The State of African Languages and the Global Language Politics: Empowering African Languages in the Era of Globalization," in Selected Proceedings of the 36th Annual Conference on African Linguistics. Editors O.F. Arasanyin and M. A. Pemberton (Somerville, MA: Cascadilla Proceedings Project), 1-13.

Semeon, N., and Mutekwe, E. (2021). Perceptions about the Use of Language in Physical Science Classrooms: A Discourse Analysis. South Afr. J. Edu. 41 (1). doi:10.15700/saje.v4lnla1781

Sharma, K. (2021), Breaking the wall to Language, Geography and Social Separation. Falling Walls Competition Entry. Availabel at: https://fallingwalls.com/discover/videos/breaking-the-wall-to-language-geography-andsocial-separation/(Retrieved October 8, 2021).

Sharma, K. (2019). June 19). Why Does Science Communication Excite Me? IndiaBioscience. Availabel at: https://indiabioscience.org/columns/opinion/ why-does-science-communication-excite-me (Retrieved October 7, 2021).

Skutnabb-Kangas, T., Maffi, L., and Harmon, D. (2003). Sharing a World of Difference: The Earth's Linguistic, Cultural and Biological Diversity. Place de Fontenoy, Paris: Unesco.

The African Technology Policy Studies Network (2010). The African Manifesto for Science, Technology and Innovation. Availabel at: https://atpsnet.org/wp-content/ uploads/2017/05/the_african_manifesto_for_sti.pdf (Retrieved September, 2021).21

Tirosh, O. (2021). April 21)Pidgin Languages: The Evolution and Examples of a Pidgin Language. Availabel at: https://www.tomedes.com/translator-hub/ pidgin-language (Retrieved September 21, 2021).

UNESCO (1981). Proceedings of the Meeting of Experts on the Transcription and Harmonization of African Languages, Niamey (Niger), 17-21 July 1978. Paris: UNESCO. Availabel at: http://www.bisharat.net/Documents/Niamey78en.htm.

Ventura, Rafael., Plotkin, Joshua. B., and Roberts, Gareth. (2021). Drift as a Driver of Language Change: An Artificial Language experiment. bioRxiv. doi:10.1101/ 2021.03.26.437270

Wellcome Trust Global monitor report (2018). Available at: https://wellcome.org/ reports/wellcome-global-monitor/2018 (Accessed August 2nd, 2021).

Wild, S. (2021). African Languages to Get More Bespoke Scientific Terms. Nature 596 (7873), 469-470. doi:10.1038/d41586-021-02218-x

Wilmot, E. M. (2003). Stepping outside the Ordinary Expectations of Schooling: Effect of Schoollanguage on the Assessment of Educational Achievement in Ghana. Paper Presented at the 47th Annual Conference. New Orleans, LA: of the Comparative and International Education Society. CIES 2003).

Zindi (2020). 1st Round of A14D-African Language DataSet Challenge. Availabel at: https://zindiafrica/competitions/ai4d-african-language-dataset-challenge (Accessed August 2nd, 2021).

Conflict of Interest: The authors declare that the research was conducted in the absence of any commercial or financial relationships that could be construed as a potential conflict of interest.

Publisher's Note: All claims expressed in this article are solely those of the authors and do not necessarily represent those of their affiliated organizations, or those of the publisher, the editors, and the reviewers. Any product that may be evaluated in this article, or claim that may be made by its manufacturer, is not guaranteed or endorsed by the publisher.

Copyright (c) 2022 Kago and Cissé. This is an open-access article distributed under the terms of the Creative Commons Attribution License (CC BY). The use, distribution or reproduction in other forums is permitted, provided the original author(s) and the copyright owner(s) are credited and that the original publication in this journal is cited, in accordance with accepted academic practice. No use, distribution or reproduction is permitted which does not comply with these terms. 